\title{
Environmental and Human Health Assessment in Relation to Pesticide Use by Local Farmers and the Cameroon Development Corporation (CDC), Fako Division, South-West Cameroon
}

\author{
Kenko Nkontcheu Daniel Brice \\ Laboratory for Biology and Applied Ecology, Department of Animal \\ Biology, Faculty of Science, University of Dschang \\ Department of Zoology and Animal Physiology, Faculty of Science, \\ University of Buea \\ Patricia Asanga Bi Fai \\ Ngameni Tchamadeu Norbert \\ Mpoame Mbida \\ Laboratory for Biology and Applied Ecology, Department of Animal \\ Biology, Faculty of Science, University of Dschang
}

doi: 10.19044/esj.2017.v13n21p454 URL:http://dx.doi.org/10.19044/esj.2017.v13n21p454

\begin{abstract}
Pesticides are widely used to reduce crop losses due to pests. This study (an initial part of a project on risk assessment and biomonitoring) deals with pesticide use patterns in the South-West, Cameroon. This descriptive and cross-sectional study was done using questionnaires randomly administered to 137 respondents. Twenty-one crops were recorded in the area with a total of 107 pesticides (60 active ingredients) used. Three illegally used pesticides were recorded (lindane, dimethoate and malathion). Application of pesticides in combination was quite common $(42.3 \%)$. Pesticide application was mainly manual using a sprayer (96.4\%) with 54\% of users experiencing health problems post-application. Because of the lack of funding and training, $19.7 \%$ sprayed pesticides without protection. For the Restricted Entry Interval (REI), 43.1\% entered the field in less than $12 \mathrm{~h}$ after pesticide application. The correlation between the REI and the number of symptoms was negative and non-significant $(\mathrm{R}=-0.07, \mathrm{p} \geq 0.05)$. The main place to store pesticides was the house $(57.7 \%)$ with the exception of CDC where pesticides were kept in a pesticide store. Some respondents (54.7\%) said they hadn't received any training on pesticide application while $20.4 \%$ of respondents failed to follow recommended doses. Surface water around farms was used by $62.1 \%$ of pesticides users for domestic purposes. Some
\end{abstract}


farmers $(46.7 \%)$ have once heard about pesticide related accident while $14.6 \%$ suffered from pesticide intoxication, the prevalence being significantly higher in males $(\mathrm{p}<0.05)$. Therefore, there is a need to regulate the pesticides sector, assess ecological risk and the bioaccumulation potential of these pesticides as well as their ability to hindrance water quality and biota.

Keywords: Pesticide, assessment, environmental health, CDC, local farmers

\section{Introduction}

The world population is increasing with an exponential speed since the demographic boom around the years 1960s. This exponential growth in numbers is accompanied by a food shortage in many countries of the world (FAO, 2010). More than 70 million people died of starvation and hugerrelated diseases as a result of famine during the $20^{\text {th }}$ century (Devereux, 2000). In order to overcome this problem of food shortage, the development of the agricultural sector stands as a solution. Farming is a viable alternative to wage labour for those who lack access to formal employment due to limited education, training and other opportunities (Abang et al., 2013). In Cameroon, the agricultural sector contributes almost $50 \%$ to all activities and the food crop sector is responsible for the greatest part of the public investment budget, since the economic factors are pushing more and more people in the agricultural sector. Many crops are then cultivated in the country either by local farmers or industrialized companies such as CDC a major development partner in Cameroon which cultivates rubber, oil palm and banana (Kimengsi and Muluh, 2013).

In the view of clearing farms, fighting against pests, improving the yield and while waiting for on-going research to come out with new farming methods and resistant varieties, the use of insecticides, fungicides and herbicides are for time being, the only means though which crop production and future harvest can be guaranteed (Souop, 2000). Pest and diseases are important constraints to vegetable production in the tropics (Abang et al., 2013). Dzemo et al. (2010) showed that insecticide application remains an important strategy for suppressing cowpea insect pests and increasing the yield. Unfortunately, extensive use of pesticide in developing countries is often accompanied with improper use (Malherbe et al., 2013). Cameroon like most developing countries is facing severe environmental and public health problems with obsolete pesticide stocks. In 1989, due to the financial crisis that hit the country, the government decided to liberalize and privatize the use of pesticides which led to an increased acquisition and use of pesticides (Souop, 2000). In Cameroon, the importation, distribution and use of pesticides are done in conditions that are far from ideal (Manfo et al., 
2010). Synthetic pesticides are widely used to reduce crop losses due to pests. However, the amount of pesticides coming in direct contact with the target pests is an extremely small percentage of the amount applied, less than $0.3 \%$ (Van der Werf, 1996). Massive quantities of pesticides are therefore released into the environment on a routine basis. Due to pesticide's toxic properties, there is an obvious risk that non-target organisms are affected, either at the application site, or due to unintentional spreading, at nearby, or even distant, areas (Akerbom, 2004). Many find their way into the aquatic system through leaching, surface run-off, spray drift, soil erosion and volatilisation. Water receiving pesticides contains fishes, zooplankton, phytoplankton, macrophytes and macro-invertebrates among which some in addition to fish serve as food to human beings. In the aquatic ecosystem, pesticides will incorporate sediments, organisms (bioaccumulation and biomagnification) or dissolve depending on the degree of persistence.

Secondary poisoning occurs if an animal eats another animal that has been fatally poisoned by a pesticide, and predator dies as a result of the poisoned prey (NPIC, 2011). Benthic communities are functionally important in transferring environmental contaminants to higher trophic levels (Akerbom, 2004).

The use of pesticides is extremely harmful to plants, animals, humans, as well as the abiotic component of the milieu (Mbiapo \& Youovop, 1993; NPIC, 2011). Due to their toxicity, pesticides can create modifications of the ecological equilibrium and decrease of the productivity of the ecosystem, by acute effects that are obvious (mortalities) or by chronic effects (carcinogenic effect, reduction of reproductive potential, teratogenicity...) that are not easy to put into evidence in situ (Garric, 1997). Pesticides have been examined in epidemiologic studies as environmental and risk factor for cancer (Teitelbaum, 2002). In addition to pesticide effects at the animal and plant population levels, processes such as nutrient cycling or soil formation can be impaired (NPIC, 2011). Putting into evidence the effects of pesticides on the aquatic medium is problematic because of a lack of biochemical, physiological and ecological bio-indicators.

This study investigated on pesticide use by small-scale farmers and the CDC in the Fako Division, South-West Cameroon. Active ingredients, application rate and devices, safety rules, possible impact on human and environment were assessed. It is the initial part of a whole project on pesticide risk assessment and biomonitoring, with the overall aim of protecting human and environmental health. 


\section{Material and Methods \\ Study design}

This descriptive cross-sectional study was carried out from November 2014 to March 2015 using random or probabilistic sampling. For this purpose, 137 structured questionnaires were randomly administered to local farmers (133) and CDC field assistants (04) of both sexes working around the Benoe Stream (figure 1). The following criteria were used: inclusion criteria (be a farmer/pesticide user, have more than 18 years and have good faith), exclusion criteria (not being a pesticide user, have less than 18 years, being uninterested in the survey).

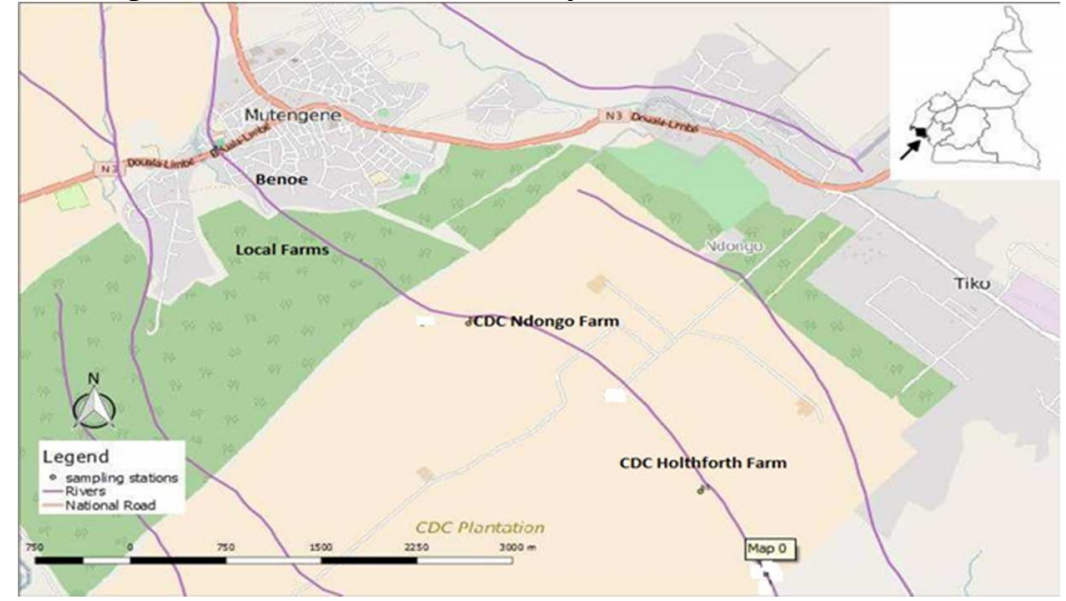

Figure 1: Map showing the Benoe stream and the location of plantations

\section{The Cameroon Development Corporation (CDC)}

The CDC is an agro-industrial complex created in 1947 aimed at acquiring, developing and operating extensive cultivation of tropical crops. With a capital of over 15 billion, CDC cultivates three main crops: rubber, oil palm and banana. The main locations of these crops are the south-west and the littoral regions of Cameroon. CDC has a work force of over 21000 workers comprising permanent and contracted workers on specified duration. It is the second largest employer in Cameroon after the state.

\section{Structure of the questionnaires}

The questionnaires were typed in English. Pidgin was used to interview farmers that could not read and write English fluently. Only those that were interested to respond were considered in the study. The structured questionnaire had many sections: personal information of the farmer (age, level of education, working experience, crops cultivated), types of pesticides applied in the farm, application device, dose and frequency, safety rules (protective clothing, recommended doses, REI, intoxication, pesticide related 
accidents), use of aquatic resource (proximity with water bodies, use of water for domestic purposes) and legality of pesticide applied.

\section{Data Analysis}

Data were complied with Microsoft Excel 2007 and analysed using the $\mathrm{R}$ programme version 3.3.1(R Core Team 2016). The chi-square test was used to check the incidence of intoxication among the respondents and the Pearson correlation was used to assess the link between pesticide application variables and health variables.

\section{Results}

\section{General information on the respondents}

A total of 137 respondents of both sexes and in various age groups, took part in this survey. The age group with more respondents was 21-40 years as shown in table I.

Table I: Age groups (years) and sexes

\begin{tabular}{|c|c|c|c|c|c|}
\hline & $18-20$ & $21-40$ & $41-60$ & 60 -above & Total \\
\hline Female & 1 & 16 & 8 & 1 & 26 \\
\hline Male & 3 & 57 & 45 & 6 & 111 \\
\hline Total & 4 & 73 & 53 & 7 & $\mathbf{1 3 7}$ \\
\hline
\end{tabular}

The majority of our respondents $(58.4 \%)$ reached secondary school. Just a few $(5.8 \%)$ did not go to school at all. The working experience was mostly between $1-15$ years $(76.6 \%)$ as shown in table II.

Table II: Level of education and working experience (years)

\begin{tabular}{|c|c|c|c|c|c|c|}
\hline & $\mathbf{0 - 1 5}$ & $\mathbf{1 6 - 3 0}$ & $\mathbf{3 1 - 4 5}$ & $\mathbf{4 6 - 6 0}$ & $\mathbf{6 1 - a b o v e}$ & Total \\
\hline No schooling & 7 & 1 & 0 & 0 & 0 & 8 \\
\hline Primary & 22 & 11 & 1 & 1 & 1 & 36 \\
\hline Secondary & 66 & 10 & 1 & 0 & 3 & $\mathbf{8 0}$ \\
\hline University & 10 & 3 & 0 & 0 & 0 & 13 \\
\hline Total & $\mathbf{1 0 5}$ & 25 & 2 & 1 & 4 & $\mathbf{1 3 7}$ \\
\hline
\end{tabular}

\section{Crops cultivated in the area}

Twenty-one (21) main crops were identified in the study area with the domination of corn (39.4\%), followed by tomato and cocoa (figure 2). Local farmers grow more than one type of crop in a single farm while crop production at CDC is specific (banana, oil palm or rubber). 


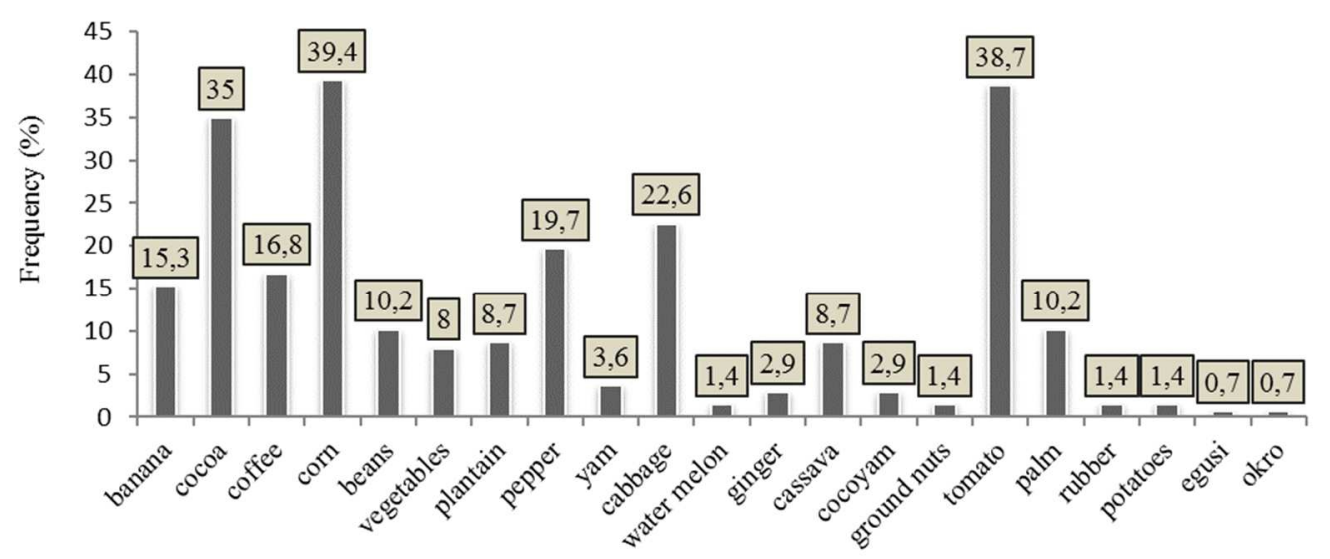

Figure 2: Crops cultivated in the area

\section{Pesticide use in agriculture}

Sixty (60) active ingredients were identified in the area with the domination of fungicides $(43.3 \%$ relative frequency to total active ingredients) as shown in table III.

Table III: Different types of pesticides (active ingredients) used in the study area

\begin{tabular}{|c|c|c|}
\hline Family & $\begin{array}{c}\text { Total number of active } \\
\text { ingredients identified }\end{array}$ & $\begin{array}{c}\text { Rel. freq. to total Active } \\
\text { Ingredients }\end{array}$ \\
\hline Fungicides & 26 & $\mathbf{4 3 . 3}$ \\
\hline Herbicides & 11 & 18.3 \\
\hline Insecticides & 20 & 33.3 \\
\hline Molluscides & 1 & 1.7 \\
\hline Nematicides & 2 & 3.3 \\
\hline Total & 60 & 100.0 \\
\hline
\end{tabular}

Everything being equal, glyphosate (herbicide) had the highest frequency $(36.5 \%)$. The most applied pesticide for each family was mancozeb for fungicides (18.2\%), glyphosate for herbicides $(36.5 \%)$, chlopyrifos for insecticides $(35.0 \%)$, melaldehyde for molluscides $(1.5 \%)$ and ethoprophos for nematicides (5.1\%).Tables IV, V, VI and VII give more details on each pesticide family with the frequency for each active ingredient.

Table IV: Fungicides

\begin{tabular}{|c|c|c|}
\hline Active ingredients & Commercial Name & $\begin{array}{c}\text { Frequency } \\
(\mathbf{\%})\end{array}$ \\
\hline Mancozeb & Dithane, Manzate, Mancozan, Penncozeb, & $\mathbf{1 8 . 2}$ \\
& Agrizeb 80WP, Cleanzeb blue 80WP, Ivory & \\
& 80WP,Mancozan bleu & \\
\hline
\end{tabular}




\begin{tabular}{|c|c|c|}
\hline Chlorothalonil & Balear 720sc, Bravo 720sc & 17.5 \\
\hline Chlorothalonil+carbendazine & Banko plus & 16.1 \\
\hline Maneb & Trimangol 80WP, Trimaneb & 11.7 \\
\hline Copper oxide & Cobra 75WG, Nordox 75WG & 9.5 \\
\hline Mancozeb+metalaxyl & $\begin{array}{c}\text { Monchamp } 72 \mathrm{WP}, \text { Mancozan Super, } \\
\text { Fongistar } 72 \% \mathrm{WP} \\
\end{array}$ & 6.6 \\
\hline Tebuconazole & Folicure 250 & 5.1 \\
\hline Copper oxide+metalaxyl & OK MIL, Cotomile & 3.6 \\
\hline Epoxiconazole & Opal, Acarius & 3.1 \\
\hline Imazalil $75 \%$ & Fungazil, Magnate & 2.2 \\
\hline Pyraclostrobin+fenpropimorph & Comet Plus 475EC & 2.2 \\
\hline Spiroxamine & Impule 800 & 1.5 \\
\hline Thiabendazole & Mertect, Tecto & 1.5 \\
\hline Azoxystrobin & Bankit & 0.7 \\
\hline Bitertanol & Baycor 500SC & 0.7 \\
\hline Boscalid & Cumora 500 & 0.7 \\
\hline Copper hydroxide & Kocide 2000 & 0.7 \\
\hline Difenoconazole & Sico & 0.7 \\
\hline Fenpropidine & Tern 750EC & 0.7 \\
\hline Fenpropimorph & Volley & 0.7 \\
\hline Horticultural oil & Banole & 0.7 \\
\hline Imazalilsulfate & Corridor $75 \mathrm{SP}$ & 0.7 \\
\hline Propiconazole & Tilt & 0.7 \\
\hline Pyrimethanil & Siganex & 0.7 \\
\hline Tridemorph & Calixin & 0.7 \\
\hline Trifloxystrobin & Tega 75 & 0.7 \\
\hline
\end{tabular}

Table V: Herbicides

\begin{tabular}{|c|c|c|}
\hline Active Ingredient & Commercial Name & Frequency (\%) \\
\hline Glyphosate & $\begin{array}{c}\text { Glycel 41\%Sl, Glyphader, Roundup, Herbistar } \\
\text { 360sl, Kalach 360 Sl, Plantop 360, Cleanfarm } \\
\text { 360sl, Finish 360Sl, Glyphosalm 360S1 }\end{array}$ & $\mathbf{3 6 . 5}$ \\
\hline Paraquat & $\begin{array}{c}\text { Gramoxone, Almoxone Super, Plantoxone Super, } \\
\text { Supraxone royal }\end{array}$ & 11.0 \\
\hline 2,4-D amine & Amistar 720SL, Dekat-D 720SL & 5.1 \\
\hline Trichlopyr & Caviar 48EC, Garlon 4E & 5.1 \\
\hline Diuron & Diuralm 800SC & 2.2 \\
\hline Nicosulfuron & Nicomais 40 & 2.2 \\
\hline Glufosinate & Basta, Forza 200SC & 1.5 \\
\hline ammonium & Elmsma 720 SL & 1.5 \\
\hline MSMA & Select 120 EC & 0.7 \\
\hline Clethodim & Touchdown & 0.7 \\
\hline Glyphotrimesium & Ristar & 0.7 \\
\hline Oxidiazon & &
\end{tabular}


Table VI: Insecticides

\begin{tabular}{|c|c|c|}
\hline Active ingredients & Commercial Name & Frequency $(\%)$ \\
\hline Chlorpyrifos & $\begin{array}{l}\text { Greyforce 480EC, Dursban, Pyriforce, } \\
\text { Cyren 480EC, Chlorcot 480EC }\end{array}$ & 35.0 \\
\hline Cypermethrin & $\begin{array}{l}\text { Cigogne 12EC, Cypercal 12EC, Cypalm } \\
\text { 200EC }\end{array}$ & 25.6 \\
\hline Imidacloprid & $\begin{array}{c}\text { Gawa 30SC, Iron 30SC, Plantima 30SC, } \\
\text { Iron 70WG }\end{array}$ & 21.9 \\
\hline $\begin{array}{c}\begin{array}{c}\text { Imidacloprid + lambda- } \\
\text { cyhalothrin }\end{array} \\
\end{array}$ & $\begin{array}{c}\text { Parastar 40WP, Dinacacoa, Lamidal } \\
\text { Gold 90EC }\end{array}$ & 19.7 \\
\hline Lindane & Gamalin 20 & 10.9 \\
\hline Thiamethoxam & Actara, Mematurin & 10.2 \\
\hline Fipronil & Capsidor 50SC & 8.0 \\
\hline Dimethoate & Dimex & 4.4 \\
\hline $\begin{array}{c}\text { Chlorpyrifos + } \\
\text { deltamethrin }\end{array}$ & Pyrinex Quick & 3.6 \\
\hline $\begin{array}{c}\text { Lambda-cyhalothrin }+ \\
\text { acetamipride }\end{array}$ & K-Optimal, Cyplandim Super & 2.9 \\
\hline $\begin{array}{c}\text { Imidacloprid + } \\
\text { cypermethrin }\end{array}$ & Gongfut 50EC & 2.2 \\
\hline Lambda-cyhalothrin & Lambdacal 100EC & 2.2 \\
\hline Malathion & Poudrox & 2.2 \\
\hline Cadusafos & Rugby & 1.5 \\
\hline Carbofuran & Bastion, Furadan & 1.5 \\
\hline Beta-cypermetrin & Akito $25 \mathrm{EC}$ & 0.7 \\
\hline $\begin{array}{c}\text { Chlorpyrifos-ethyl } \\
\text { +cypermethrin }\end{array}$ & Epervier $220 \mathrm{EC}$ & 0.7 \\
\hline Deltamethrin & Decis 25EC & 0.7 \\
\hline Imidacloprid + thiram & Imidalm T 275FS & 0.7 \\
\hline Novaluron+bifenthrin & Diamond Fast & 0.7 \\
\hline Oxamyl & Vydate & 0.7 \\
\hline
\end{tabular}

Table VI presents three insecticides with illegal use: malathion (poudrox), lindane (gamalin 20) and dimethoate (dimex).

Table VII: Molluscides and Nematicides

\begin{tabular}{|c|c|c|c|}
\hline Active Ingredient & Commercial Name & Frequency (\%) & Family \\
\hline Ethoprophos & Mocap & 5.1 & Nematicide \\
\hline Metaldehyde & $\begin{array}{c}\text { Deadline bullets, } \\
\text { Limac 5G }\end{array}$ & 1.5 & Molluscide \\
\hline Terbufos & Counter & 1.5 & Nematicide \\
\hline
\end{tabular}

It appears from table VII that the most used nematicide was ethoprophos $(5.1 \%)$ while metaldehyde was the only used molluscide.

Decision on pesticides to use and pesticide mixtures 
Most of the farmers $(37.2 \%)$ rely on pesticides labels to make their choice even though some may prefer advice from friends $(21.9 \%)$. Three main spraying devices were used: manual $(96.4 \%)$, tractor $(2.9 \%)$ and aircraft $(1.5 \%)$. Pesticide use was mainly in combination $(56.9 \%)$ as seen on figure 3. Furthermore, $81.0 \%$ of users applied the same dose as the previous crop season, $16.1 \%$ increased the dose, $2.2 \%$ decreased and $0.7 \%$ had no response.

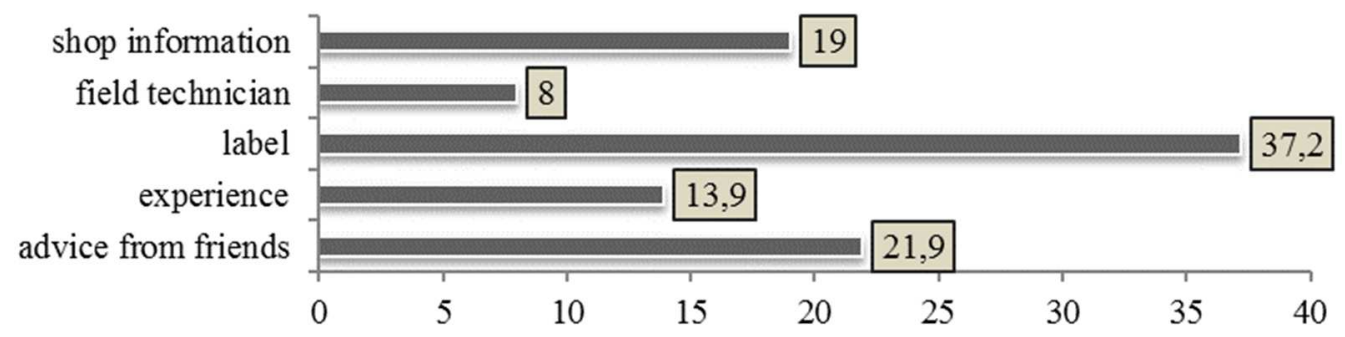

Figure 3: How do farmers decide on pesticides to use

\section{Knowledge on pesticide use and safety rules}

Their knowledge on pesticide use and safety was not the best. About $63 \%$ didn't know if the chemicals they use are legal in Cameroon or not. With regard to intoxication, $14.6 \%$ of them had suffered from it. More than $20 \%$ of the respondent failed to follow recommended doses because those doses aren't accurate on their opinion (figure 4).

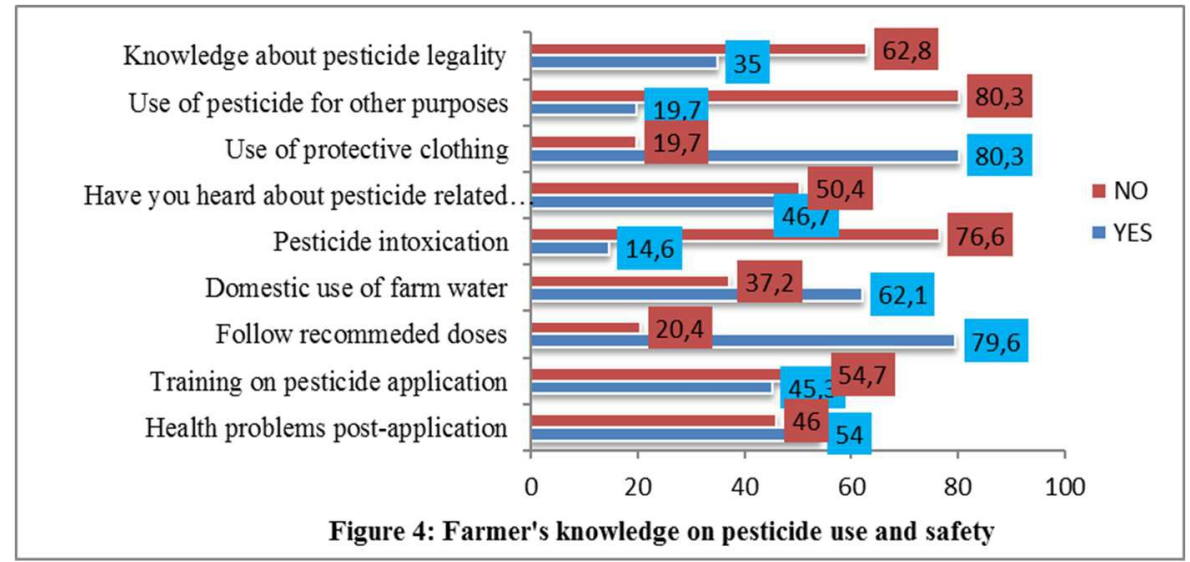

\section{Health problems post-application}

Fourteen (14) post-application symptoms were recorded in our survey, ranging from catarrh (1.4\%) to nausea $(29.9 \%)$ as shown on figure 5 . 


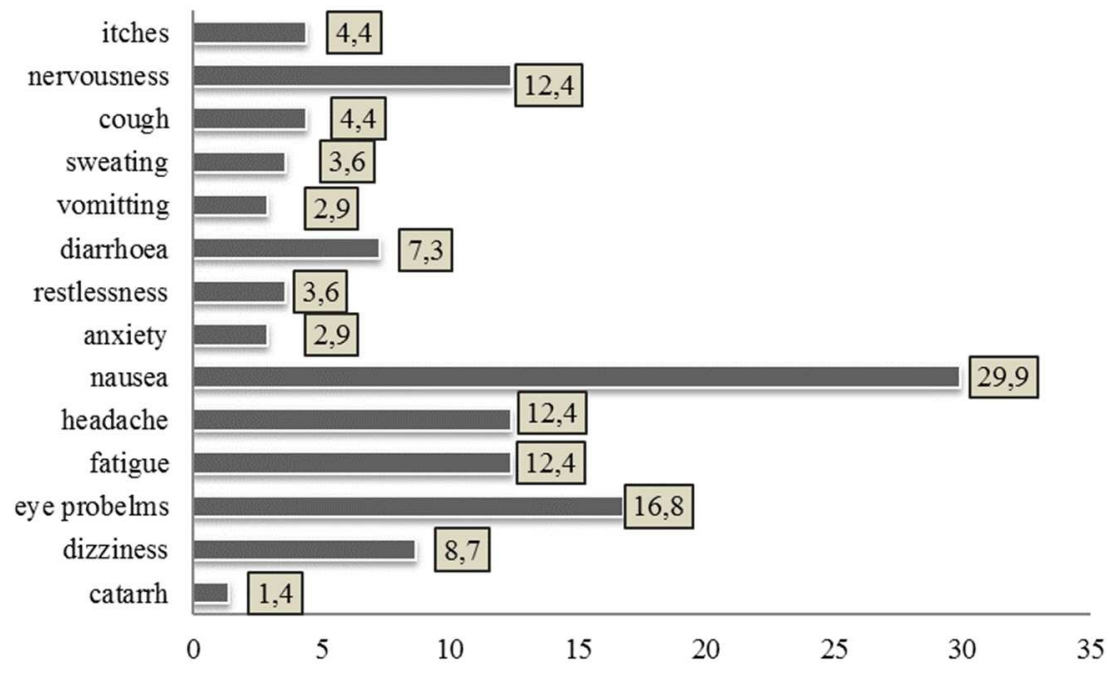

Figure 5: Prevalence of post-application symptoms (\%)

\section{The Restricted Entry Interval (REI)}

The REI was not respected by $43.1 \%$ of farmers who said they reentered the farm less than 12 hours after application. Fifty-three percent (53\%) entered the farm after 12 hours while $4.0 \%$ had no specific duration.

\section{Management of empty sachets and containers}

Empty pesticide containers were mainly kept $(32.8 \%)$ in case of containers or burn $(24.8 \%)$ when it was a sachet. Nevertheless, some pesticide users threw empty containers in the bush or in water (figure 6).

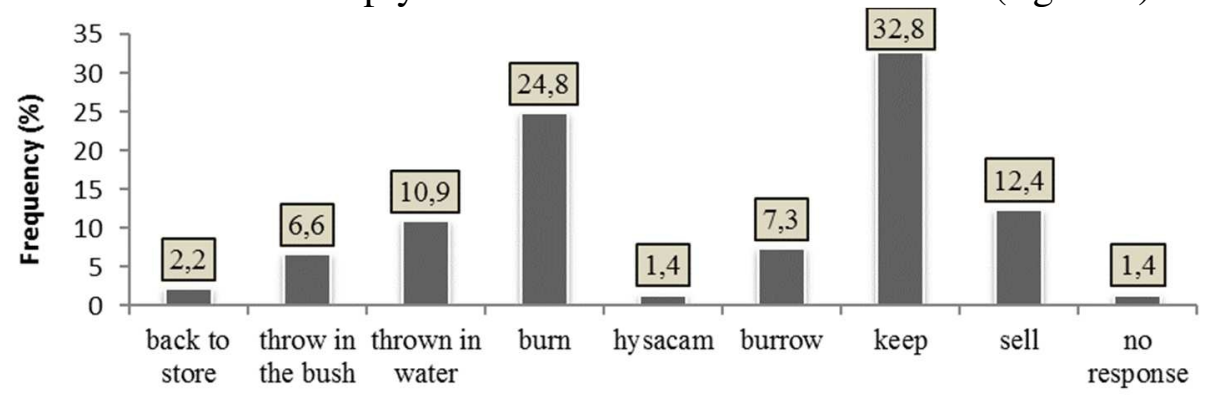

Figure 6: Management of empty pesticide containers/sachets 

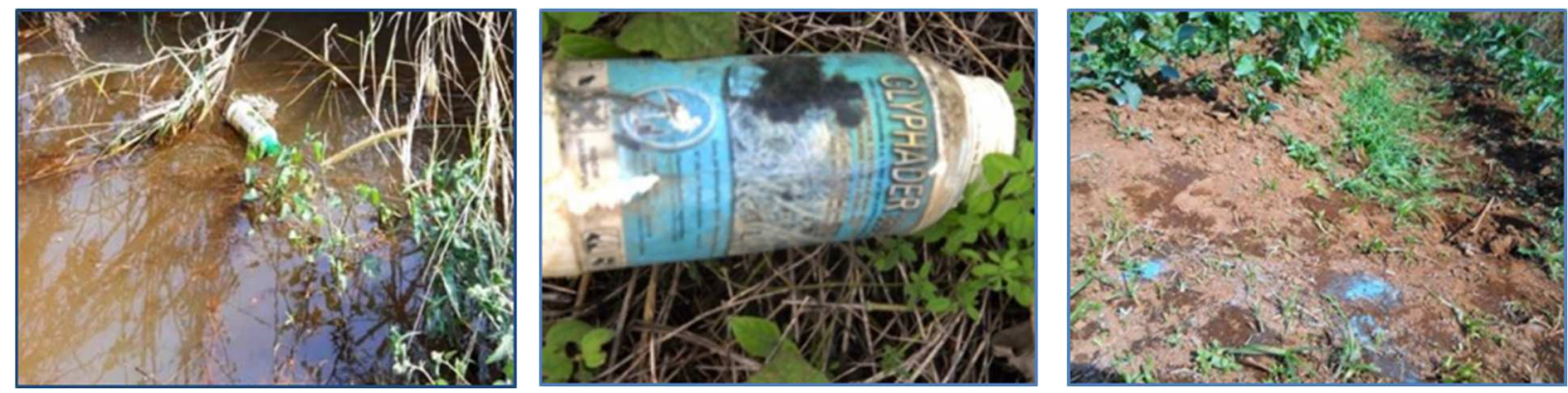

Figure 7: Empty pesticides containers in water, in the bush and pesticide remains on the soil

\section{Place of storage of pesticides}

Pesticides were stored mainly at home (57.5\%) for local farmers while at CDC agrochemicals were kept in the pesticide store (figure 8).

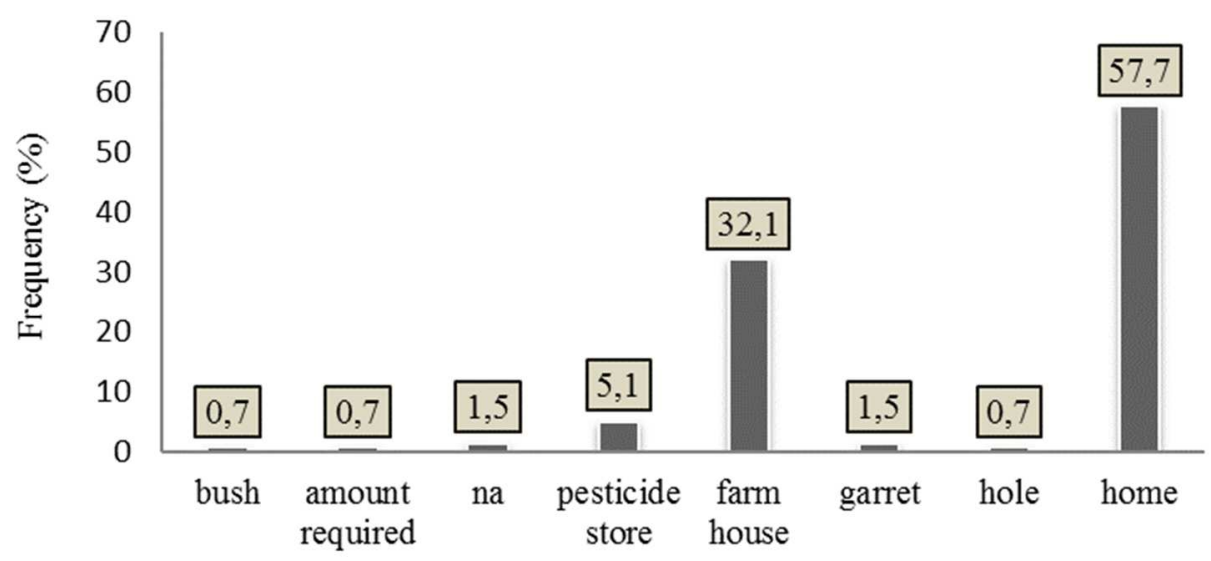

Figure 8: Place of storage of chemicals

\section{Use of aquatic resources}

About $62 \%$ of farmers used their farm water for domestic purposes (washing, irrigation, swimming, fishing). We observed many children swimming and drinking, women washing clothes and men doing fishing activities in the Benoe stream. The distance between the farm and the stream was evaluated as shown on figure 9. The majority of the farms $(72.3 \%)$ were close to the stream and at CDC, there is always a stream close to/or crossing banana plantations for irrigation, pesticide application and banana processing purposes. 


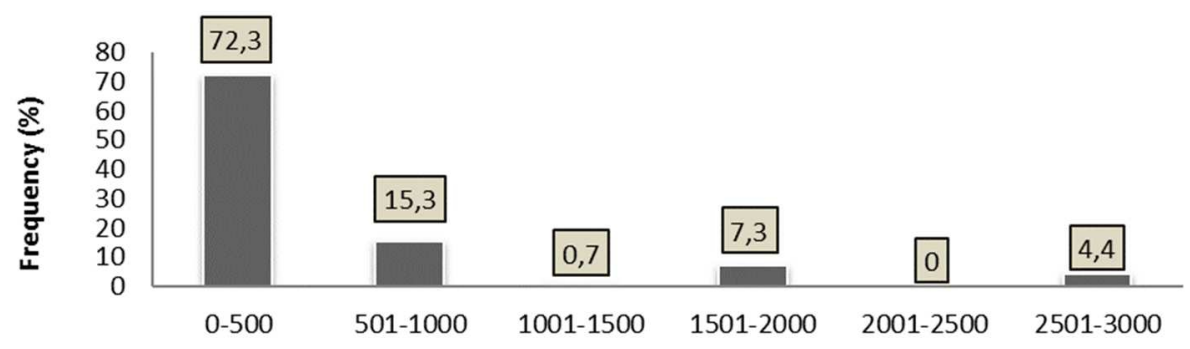

Figure 9: Distance (m) between the farm and the nearest water body

\section{Impact of pesticide application scheme on post application symptoms}

Based on the number of post-application symptoms, the only positive and significant correlation was between the age and the number of postapplication symptoms $(\mathrm{R}=0.227, \mathrm{p}<0.05)$; the greater the age, the greater the number of post-application symptoms.

\section{Impact of the sex on pesticide application}

With regard to pesticide use, the only significant difference was observed in the number of users that had been intoxicated with pesticides. The number of intoxication was higher in males $(13.1 \%)$ than females $(1.5 \%)$ with a significant difference $(\mathrm{p}<0.05)$ (Table VIII).

Table VIII: Influence of the sex on pesticide application scheme

\begin{tabular}{|l|c|c|}
\hline \multicolumn{1}{|c|}{ Variables } & X-squared & p-value \\
\hline Sex vs. Use of protective clothing & 0.0046 & 0.95 \\
\hline Sex vs. Health problems post-application & 0.1747 & 0.68 \\
\hline Sex vs. Training received on pesticide use & 0.0104 & 0.92 \\
\hline Sex vs. Use pesticide for other purposes & 0.2302 & 0.63 \\
\hline Sex vs. Follow recommended dose & 0.5039 & 0.48 \\
\hline Sex vs. Know about legality of pesticides & 6.5904 & 0.08 \\
\hline Sex vs. Heard about pesticide accident & 2.5303 & 0.47 \\
\hline Sex vs. Restricted Entry Interval & 11.7180 & 0.38 \\
\hline Sex vs. Post application symptoms & 3.4117 & 0.84 \\
\hline Sex vs. Pesticide intoxication & 9.51141 & $\mathbf{0 . 0 2} *$ \\
\hline
\end{tabular}

*Correlation is significant at 0.05 levels.

\section{Discussion}

This work was aimed at investigating on pesticide use patterns and implications on human and environmental health in South-West Cameroon. Extensive agriculture is quite developed in this area (CDC) and 
generalisation of results at the national level should be done with care. Secondary school was the highest level of education for the majority of respondents. This may be as a result of economic factors in the country, pushing more and more people into agriculture. This corroborates with results of Nanfa et al. (nd) in Yaounde and Nyakundi et al. (2010) in Kenya who related it to the lack of jobs and search for school fees. The educational background had no statistical link $(\mathrm{p}>0.05)$ with pesticide application scheme (non-respect of doses, inexistent protective clothing, post-application symptoms and use of farm water for domestic purposes, training on pesticide use).

Twenty-one main crops were recorded in the area. The South-West Region is one of the most fertile zones in the country and is very suitable to agriculture. Corn was the most frequent crop; this cereal is highly appreciated in many traditional meals and is also for commercial purposes. It is very resistant to pests and can be stored for a longer period of time in its various forms. After corn, came tomato (38.7\%) and cocoa (35.0\%). Those two tropical crops are very common in the area and their production depends on market demands and the type of soils.

All the farmers $(100 \%)$ interviewed used pesticides and were all $(100 \%)$ interested in the findings of our research. Pesticide use in the area is quite high probably because of the proliferation of pests which have developed resistance over time (Tetang \& Foka, 2008). Parrot et al. (2008) found that the average number of agro-chemical inputs use among farmers doubled between 1995 and 2004 in Muea (South West Cameroon). This survey identified 107 pesticides (60 active ingredients) used sprayed by farmers and most of those agricultural inputs are extremely hazardous. The most used pesticide was glyphosate $(36.5 \%)$. This may be related to farmer's preference, experience and advice from friends or shop information.

Fungicides were the most used active ingredients, suggesting that fungal diseases could be the main threat to crops in the area. Mbiapo and Youovop (1993) in a pilot study in Cameroon also realised that insecticides and fungicides are the two groups of pesticides making up the bulk of agricultural inputs used. In this study, molluscides were less used, probably because of the constant capture of hundreds of snails on a daily basis by local populations to produce "Congo meat", rendering snail control more mechanical than chemical. Nevertheless, companies such as CDC discourage people from eating snails captured from plantations. Because of their slow motion and soft body, they have a great bioaccumulation potential for pollutants. The practice of hand-picking can highly contribute to the reduction of snail abundance and significantly reduce pesticide-dependence.

Pesticide application was mainly done manually with the common sprayer known as "Matabi" hung on the back side of the body. Aircraft 
application was only done at CDC especially with fungicides and in banana farms. Manual application with inappropriate protective equipment is very risky; also application with helicopters can be highly hazardous to non-target organisms and people living around. In a study led by Matthews et al. (2003) in Cameroon, over $83 \%$ of the individual small-scale farmers did not use protective clothing, because it was either unavailable or was too expensive.

In every CDC banana farm, there is a notice indicating that the plantation is often sprayed with fungicides and people should enter with care. Health problems associated with pesticides applications are usually blamed on the pesticides without considering how they are applied (Matthews et al., 2003).

Fifty-six point nine percent $(56.9 \%)$ of farmers applied pesticide in combination either to make sure it works or to save time. Agricultural pesticides are often used in combination with each other to protect crops, so the risk for additive or even synergistic effects is obvious (Akerbom, 2004). Such mixtures affect the aquatic community at low concentrations (Relyea, 2009). Also, 16.1\% of users said they increased the dose as compared to the previous crop season. This already implies a failure to follow recommended doses. Using pesticide in combination is not advisable because contrary to the common belief of farmers, mixture of chemical may have additional, synergistic or antagonist effects. On farmers' option, mixing pesticides have additional effects. According to Akerbom (2004), additive effect can be expected for compounds with the same mode of action, while synergistic effects trigger a more than additive effect in the exposed organisms. The practices followed by pesticide users in Cameroon are not adequate to minimize harmful effects on humans, animals, plants and the environments (Mbiapo and Youovop, 1993).

Twenty point four percent $(20.4 \%)$ of users failed to follow recommended doses because they though recommended doses were not accurate and they sometimes had more pest incidence in the farm. This may explain why cases of intoxication were recorded and some users $(46.7 \%)$ testified having heard about pesticide related accident in the locality such as death of animals, death of man. Apart from crops, $19.7 \%$ of users used pesticides for other purposes such as repelling snakes. Amuoh (2011) reported that lindane formerly used for the control of cocoa mirids is poured into rivers, lakes and streams to kill fish, which is then sold for human consumption. This goes along with those not using protective clothing due to lack of funding, ignorance and negligence, and to the best of our knowledge, ignorance has never helped a community.

Protective equipment used during application was inexistent or inefficient in most cases. Using pesticides with inappropriate protection expose farmers to those chemicals that may enter their body through the 
skin, eyes or lungs leading to several allergy-like symptoms. In a case study done in Cameroon, Amuoh (2011) reported that farmers were spraying without body covering, smoking, eating and drinking during spraying or using fake, adulterated and expired pesticides, using pesticides meant for cocoa or cotton on fruits and vegetables, and sometimes the equipment they use leak. Cameroonian farmers had adopted old clothing as well as hard leather boots for use during mixing and spraying of pesticides (Matthews et al., 2003).

Post-application symptoms have been signalled by $54 \%$ of pesticide users. There was a positive and significant correlation between the number of symptoms and the age $(\mathrm{R}=0.227 ; \mathrm{p}<0.05)$. This may be due to a gradual reduction in the power of the immune system as age increases. Fourteen (14) post-application symptoms were recorded. This is an indication that pesticides may be hazardous to humans and hence, the environment. The effect of these inputs may be acute or chronic (Garric, 1997). Chronic effects of pollutants many bring about severe effect such as mutations, cancers, total or partial sterilisation, and the on-set needs a latency time in terms of years and even decades (Ramade, 2008). Pesticides have a very negative impact on male reproductive potential (Manfo et al., 2010). Animals can be exposed to pesticides directly by breathing them in, getting the pesticides on their skin, or eating them (NPIC, 2011). In this survey, symptoms reported by farmers such as eye irritation, itches, catarrh were the proof of dermal exposure and inhalation, which may later affect the nervous system resulting in dizziness, headache and fatigue. Vomiting and nausea reported by some farmers are signs of digestive tract exposure. In a survey carried out by Tetang \& Foka (2008) in Njombé (Littoral Region, Cameroon), they found out that farmers were not very knowledgeable on pesticide use and were at risk of being contaminated. They reported three main post-application symptoms: nausea, chest pain and respiratory disorders. Also, they noted negligence in pesticide storage and use of inappropriate equipment (manual spray, lack of protective clothing), this study came out with the same findings.

The sex of the pesticide users did not have any significant impact on pesticide application scheme. Currently, both men and women are involved in agricultural activities. Nevertheless, men significantly suffered from intoxication more than women $(\mathrm{p}<0.05)$. In fact, men may exhibit more negligence, usage of inappropriate protective clothing, non-respect of recommended doses and lack of commitment in the work. One of two workers assigned to pesticide handling at IRAD Njombé was reported died by Tetang \& Foka (2008), following pesticide contamination. Some of the chronic signs may appear even after eight years. Some pesticides last a long time in the environment, and may pose risks to living things many years after 
they were last used (NPIC, 2011). In the course of our survey, an anonymous source mentioned a dead farmer in Tiko following pesticide contamination.

The number of post application symptoms can be linked to the REI. Some farmers $(43.1 \%)$ re-entered the farm less than 12 hours after pesticide application. US-EPA (2017) recommends $12 \mathrm{~h}$ as the REI for most pesticides.

The correlation between the REI and the number of symptoms was negative and non-significant $(R=-0.07, p \geq 0.05)$, suggesting that the number of symptoms decreased when the REI increased. Entering the farm several hours or days after pesticide application reduced the number of postapplication symptoms.

The way users managed empty containers and sachets could be another source of exposure. Empty sachets were mainly thrown in the water or in the bush; this practice could favour the accumulation of pesticide residues into the environment. Also, users mainly stored their pesticides at home $(57.7 \%)$; this practice was also identified by Tetang \& Foka (2008) in Njombé and Matthews et al. (2003) discovered that large plastic containers were washed and used for other purposes such as the storage of grain, kerosene and palm oil by farmers in Cameroon.

Farm water was used by $62.1 \%$ of respondents for domestic purposes. This is quite hazardous to human and environmental health depending on the transfer and concentration factors of the pollutant (Ramade, 2008). This practice may constitute a source of contamination via dermal exposure or ingestion. Effects of pesticides at the organism or ecological levels are usually considered to be an early warning indicator of potential human health impacts (FAO, 2010). The presence of a stream seemed to be the key factor to create a farm because $72.3 \%$ of farms were less than $500 \mathrm{~m}$ far from the stream. At CDC, all banana plantations were close to a stream or a stream was crossing the farm. This proximity of farms to the stream is quite problematic because pesticides will finally find their way into the aquatic ecosystem. From a study led by Carter (2000), pesticides get into water trough diffuse sources (spray drift, volatilisation and precipitation, leaching, drainflow and throughflow, base flow seepage) or point sources (farm activities, direct contamination and overspray). Pesticide toxicity in the aquatic ecosystem depends on water parameters such as temperature and $\mathrm{pH}$ (Hasimoto, 1982). Abiotic degradational processes for pesticides include hydrolysis, photolysis and oxidation (FAO, 2010); such processes may impair water physico-chemistry because water parameters are closely related to each other.

Some pesticide users (54.7\%) replied they had not received any training on pesticide application. This may explain all the misuses described in this study. At CDC, even though a lay worker applies pesticides in a blind 
way, they received training from field assistants, but they are not very knowledgeable about the name of chemicals used and the dose.

Malathion is banned for use of cocoa but farmers used it indiscriminately on any crop while lindane and dimethoate are banned in Cameroon (MINADER, 2013). In the same line, Nanfa et al. (nd) realised that lindane was used by gardeners of the Yaoundé VII municipality idem with Amuoh (2011) who realised that some farmers $(20 \%$ of the interviewed), claim they know of illegal use of pesticides: use of expired, banned, fake and adulterated pesticides. This implies farmers had little knowledge on pesticide homologation list and some agro-chemicals may enter the country via unorthodox routes which are failures of the pesticide regulation scheme. According to Souop (2000) and Manfo et al. (2010), pesticide importation and distribution in Cameroon is done in conditions that are far from ideal; also legislation on pesticide use in Cameroon in still in the draft stage (Mbiapo and Youovop, 1993). The dilemma of cost/efficacy versus ecological impacts and access to modern pesticide formulations at low cost remains a contentious global issue (FAO, 2010). Laboratory models have to be developed to determine in advance those pesticides having high persistence and possible biological concentration in the environment (Hashimoto, 1982) since the major threat to the aquatic ecosystem may be the lack of information available about pesticides (Akerbom, 2004).

\section{Conclusion}

Agricultural activities are widespread in the South-West Region, carried out by small-scale farmers or large companies such as the CDC. Pesticide use in farms is a common rule given the number pesticides that were recorded and the fact that all the farmers used these agrochemicals. The use of protective clothing, knowledge on pesticide regulation and environmental protection is still a mystery for most of the pesticide users hence a good number of post-application symptoms recorded as well as cases of intoxication. There is therefore a need for sensitization and training on pesticide use and the implications of misuse on human and environmental health. Further studies should carry out a preliminary risk assessment with these pesticides in order to predict the risk they can cause in aquatic and terrestrial systems. Also the bioaccumulation potential of these compounds and their ability to impair water quality and aquatic biota should be evaluated. Measures should be put into action by stakeholders to reduce pesticide entry into water: education of operator, good regulation, maintenance of spraying devices, restricted application areas, creation of buffer zones between farms and water. The government should re-start to purchase and distribute large quantities of pesticides to farmers in the various regions as it was the case before the economic crisis in 1989. 


\section{Acknowledgments}

The research team is very grateful to CDC officials who provided a letter of acceptance for data collection in the company and all the small scale farmers who cooperated in the exercise. Thanks to all the guides and translators in the fields. Thanks to Mr. Geraud C. Tassé for proof-reading the work.

\section{References:}

1. Abang, A.F., Kouame, C.M., Abang, M., Hannah R. \& Fotso, A.K. (2013). Vegetable growers' perception of pesticide use practices, cost, and health effects in the tropical region of Cameroon. Intl. J. Agron. Plant. Prod. 4(5): 873-883.

2. Akerbom, N. (2004). Agricultural pesticide toxicity to aquatic organisms: A literature review. Department of Environmental Assessment, Swedish University of Agricultural Science, Uppsala. $31 \mathrm{p}$.

3. Amuoh, C.N. (2011). A case study of health risk estimate for pesticide-users of fruits and vegetable farmers in Cameroon. M.Sc. Thesis, Gent University, 104 p.

4. Carter, A. (2000). How pesticides get into water and proposed reduction measures. Pesticide Outlook, European Crop Protection Association, DOI: 10.1039/b006243j: 149-156.

5. Devereux, S. (2000). Famine in the twentieth century. IDS Working Paper 105. 40p.

6. Dzemo, W.D., Niba, A.S. \& Asiwe, J.A.N. (2010). Effects of insecticide spray application on insect pest infestation and yield of cowpea [Vignaunguiculata (L.) Walp.] in the Transkei, South Africa. African Journal of Biotechnology 9 (11):1973-1979.

7. FAO (2010). Évaluation de la sécurité alimentaire mondiale. Comité de la sécurité alimentaire mondiale, Rome, 28 Mai -1 ${ }^{\text {er }}$ Juin 2001.

8. FAO (2010). Pesticides as water pollutants. Available online at http://www.fao.org/docrep/w2598e/w2598e07.htm (Accessed on 1211-2010).

9. Garric, J. (1997). La contamination des eaux superficielles par les produits phytosanitaires: les effets sur le milieu aquatique. Ingénieries-EAT 10:55-64.

10. Hashimoto, Y. (1982). Effects of pesticides on aquatic organisms and their environment. J. Pesticide Sci. 7:281-287.

11. Kimengsi, J.N., Muluh N.G. (2013). A comparative assessment of the effect of climate variations on the crops of the Cameroon development corporation (CDC): Adaptation Options. Env. Nat. Res. Research. 3(1):144-156. 
12. Malherbe, W., Van Vuren, J.H.J. and Wepener, V. (2013). Preliminary risk assessment of common-use pesticides using PRIMET and PERPEST pesticide risk models in a semi-arid subtropical region. Water SA 39(5):599-609.

13. Manfo, F.P.T., Moundipa, P.F., Déchaud, H., Tchana, A.N., Nantia, E.A., Zabot, M.T. \& Pugeat, M. (2010). Effect of agropesticides use on male reproductive function: a study on farmers in Djutitsa (Cameroon). Env. Toxicol. DOI 10.1002:1-10.

14. Matthews, G., Wiles, T. \& Baleguel, P. (2003). A survey of pesticide application in Cameroon. Crop Protection 22:707-714.

15. Mbiapo, F.D. \& Youovop, G. (1993). Pesticides use in Agriculture, Public health and Animal Husbandry in Cameroon. In Impact of Pesticides use on Health in developing Countries (IDRC) IDRC International Development Research Centre. 352p.

16. MINADER [Ministère de l'Agriculture et du Développement Rural] (2013). Liste des pesticides homologués au Cameroun au 31 juillet 2013. Liste réservée au grand public. 40p.

17. Nanfa, D., Atogho T.B., Ndonwi, E.N. \& Fopa, L.G.B. (nd). Environmental and health risk associated with the dissemination of persistent organic pollutants (pops) in Yaoundé. Topic A10: Public health and exposure studies, $7 \mathrm{p}$.

18. NPIC [National Pesticide Information Center] (2011). Ecotoxicology, Topic Fact Sheet. http://www.npic.orst.edu (Accessed on $1^{\text {st }}$ August 2016).

19. Nyakundi, W.O., Magoma, G., Ochara,Nyende, A.B. (2010). A survey of pesticide use and application patterns among farmers: a case study from selected horticultural farms in rift valley and central provinces, Kenya. Institute of Biotechnology and Research, Nairobi, Kenya. pp 618-630.

20. Parrot, L., Dongmo, C., Ndoumbe, M. \& Poubom, C. (2008). Horticulture, livelihoods and urban transition in Africa: evidence from south-west Cameroon. Agricultural Economics 39: 245-256.

21. R Core Team (2016). R: A language and environment for statistical c omputing. R Foundation for Statistical Computing, Vienna, Austria. URL:https://www.R-project.org/.

22. Ramade, F. (2008). Ecotoxicologie. Société Nationale de Protection de la Nature. $4 \mathrm{p}$.

23. Relyea, R.A. (2009). A cocktail of contaminants: how mixtures of pesticides at low concentration affect aquatic communities. Ecologia, 159: 363-376. 
24. Souop, D. (2000). Obsolete pesticides stocks in Cameroon. OECDFAO-UNEP Workshop on obsolete pesticides, Alexandra-Virgina, USA. 6p.

25. Teitelbaum, S.L. (2002). Questionnaire assessment of nonoccupational pesticide exposure in epidemiologic studies of cancer. Journal of Exposure Analysis and Environmental Epidemiology 12:373-380.

26. Tetang, T.J. \& Foka, G. (2008). Utilisation des pesticides dans la zone agricole du Moungo- évaluation de l'impact sur l'environnement, la santé des populations et solutions envisageables: cas de la localité de Njombé dans l'arrondissement de Njombé-Penja. African Front for the protection of Nature and Man.7p.

27. Van der Werf, H.M.G. (1996). Assessing the impact of pesticides on the environment. Agriculture, Ecosystems and Environment 60: 8196.

28. US-EPA (2017). Restrictions to protect workers after pesticide applications. URL: https://www.epa.gov/pesticide-workersafety/restrictions-protect-workers-after-pesticide-applications\#rei (Accessed: July 2017). 